\title{
PENGGUNAAN TEKNIK SHOW NOT TELL DALAM MENINGKATKAN KEMAMPUAN MENULIS TEKS ANEKDOT
}

\author{
Irpan Maulana ${ }^{1}$, Desti kusmayanti ${ }^{2}$ \\ 1,2STKIP Subang \\ 1irpanstkipsubang@gmail.com, ${ }^{2}$ dkusmayanti@gmail.com
}

\begin{abstract}
The ability of students in writing is still low, especially in writing anecdotal texts, so we need a learning innovation that can improve students' abilities through the use of show not tell techniques. This study aims to improve students 'anecdotal text writing skills by applying the Show not tell technique, as well as describing the improvement in students' anecdotal text writing skills by applying the show not tell technique. The population in this study were all grade $X$ students of SMA Negeri 1 Ciasem. The research method used was a pre-experimental design with One-Group Pretest-Posttest Design. Data collection techniques used in this study were writing tests. The data form of this research is in the form of an assessment of learning outcomes that illustrate the skills of students in writing anecdotal texts. Data analysis of test results is done by collecting data writing anecdotal texts, correcting, determining values and processing values. The results showed a significant increase in anecdotal text writing test scores with pretest and posttest. Overall pretest results of students obtained an average value of 59.09 while the overall posttest results of students scored with an average of 78.27. Thus it can be concluded that the learning outcomes of writing anecdotal texts by using show not tell technique increases.
\end{abstract}

Keywords: Writing, Anecdotal Text, Show Not Tell Technique.

\begin{abstract}
ABSTRAK
Kemampuan siswa dalam menulis masih rendah, khususnya dalam menulis teks anekdot, sehingga diperlukan suatu inovasi pembelajaran yang dapat meningkatkan kemampuan siswa melalui penggunaan teknik show not tell. Penelitian ini bertujuan untuk meningkatkan kemampuan menulis teks anekdot siswa dengan menerapkan teknik Show not tell, serta mendeskripsikan peningkatan kemampuan menulis teks anekdot siswa dengan menerapkan teknik show not tell. Populasi dalam penelitian ini yaitu seluruh siswa kelas X SMA Negeri 1 Ciasem. Metode penelitian yang digunakan adalah pre-eksperimental dengan rancangan One-Group Pretest-Posttest Design. Teknik pengumpulan data yang digunakan dalam penelitian ini yaitu tes menulis. Wujud data penelitian ini berupa penilaian dari hasil belajar yang menggambarkan keterampilan siswa dalam menulis teks anekdot. Analisis data hasil tes dilakukan dengan cara mengumpulkan data menulis teks anekdot, mengkoreksi, menentukan nilai dan mengolah nilai. Hasil penelitian menunjukkan adanya peningkatan yang signifikan pada nilai tes menulis teks anekdot dengan pretest dan posttest. Secara keseluruhan hasil pretest siswa memeroleh nilai rata-rata sebesar 59,09 sedangkan hasil posttest keseluruhan siswa mendapat nilai dengan rata-rata sebesar 78,27 . Dengan demikian dapat
\end{abstract}


Didaktik : Jurnal IImiah PGSD STKIP Subang,

disimpulkan bahwa hasil pembelajaran menulis teks anekdot dengan menggunakan teknik show not tell meningkat.

Kata kunci : Teks anekdot, Teknik Show not tell.

\section{A. Pendahuluan}

Keterampilan berbahasa mempunyai empat komponen, yaitu keterampilan menyimak (listening skills), keterampilan berbicara (speaking skills), keterampilan membaca (reading skills) dan keterampilan menulis (writing skills). Setiap keterampilan memiliki hubungan erat dengan proses-proses yang mendasari bahasa. Bahasa seseorang mencerminkan pikirannya. Semakin terampil seseorang berbahasa, semakin cerah dan jelas pula jalan pikirannya. Keterampilan hanya dapat diperoleh dan dikuasai dengan jalan praktik dan banyak latihan. Melatih keterampilan berbahasa berarti pula melatih keterampilan berpikir (Tarigan, 1980:2).

Dalam kehidupan modern ini, jelas bahwa keterampilan menulis sangat dibutuhkan. Kiranya tidaklah terlalu berlebihan bila kita katakan bahwa keterampilan menulis merupakan suatu ciri dari orang terpelajar. Sehubungan dengan hal tersebut Tarigan (1982:4) menyata- kan bahwa seorang penulis yang mengatakan bahwa menulis dipergunakan, melaporkan/ memberitahukan, dan memengaruhi, dan maksud serta tujuan seperti itu hanya dapat dicapai dengan baik oleh orangorang yang dapat menyusun pikirannya dan mengutarakannya dengan jelas, kejelasan ini bergantung pada pikiran, organisasi, pemakaian kata-kata, dan struktur kalimat.

Setiap penulis senantiasa akan memproyeksikan sesuatu mengenai dirinya ke dalam bentuk tulisan. Bahkan dalam tulisan yang objektif sekali pun keadaan penulis masih tetap tercermin, karena gaya tulisannya senantiasa dipengaruhi oleh nada yang sesuai dengan keinginan penulis yang bersangkutan. Ada berbagai macam tujuan yang ingin dicapai setiap jenis tulisan, namun menurut D'Angelo (Salam, 2009: 3) tujuan penulisan itu dapat dibagi menjadi empat tujuan utama, yaitu, tulisan yang bertujuan memberitahukan atau mengajar disebut wacana informative (informative discourse), tulisan yang 


\section{Didaktik : Jurnal IImiah PGSD STKIP Subang, ISSN Cetak : 2477-5673 ISSN Online : 2614-733X Volume VI Nomor 1, Juni 2020}

bertujuan meyakinkan atau mendesak disebut wacana persuasive (persuasive discourse), tulisan yang bertujuan menghibur/ menyenangkan atau yang mengan-dung tujuan estetik disebut tulisan literer atau wacankesastraan (literary discourse), serta tulisan yang bertujuan mengekspresikan perasaan dan emosi disebut wacana ekspresif (expressive discourse).

Lebih lanjut, D'Angelo (Salam, 2009: 3) menyatakan bahwa tujuan tersebut sering muncul secara bersamaan, bahkan sering ada jenis, tujuan tulisan yang tidak termasuk dalam keempat tujuan tersebut diatas. Hal ini disebabkan karena cara pandang yang berbeda.

Pada prinsipnya fungsi utama dari tulisan adalah sebagai alat komunikasi yang tidak langsung. Menulis sangat penting bagi pendidikan karena memudahkan para pelajar berfikir. Juga dapat menolong kita berfikir kritis. Juga dapat mempermudahkan kita me-rasakan hubungan-hubungan, mem-perdalam daya tanggap atau persepsi kita, memecahkan masalah-masalah yang kita hadapi, menyusun urutan bagi pengalaman. Melalui menulis kita dapat menuangkan apa yang kita rasakan, dan apa yang kita inginkan. Selain itu menulis juga dapat dijadikan sebagai sarana untuk menyimpan kenangan mengenai sesuatu dalam bentuk tulisan.

Menurut Dalman (2016:6) menulis memiliki banyak manfaat yang dapat dipetik dalam kehidupan ini, diantaranya: (1) peningkatan kecerdasan, (2) pengembangan daya inisiatif dan kreativitas, (3) penumbuhan keberanian, (4) pendorongan kemauan dan kemampuan mengumpulkan informasi.

Salah satu kegiatan menulis dalam materi pembelajaran di SMA pada kurikulum 2013 adalah teks anekdot. Anekdot tidak semata-mata menyajikan hal-hal yang lucu-lucu, guyonan, ataupun humor. Akan tetapi, terdapat pula tujuan lain di balik cerita lucunya itu, yakni berupa pesan yang diharapkan bisa memberikan pelajaran kepada khalayak.

Kegiatan menulis teks anekdot merupakan salah satu ranah keterampilan menulis yang harus diajarkan kepada siswa. Memiliki keterampilan menulis teks anekdot dapat berkaitan erat dengan latihan mempertajam imajinasi/ daya khayal, mengkritik dan kreatifitas siswa. Siswa mampu memahami teks anekdot 
Didaktik : Jurnal IImiah PGSD STKIP Subang, ISSN Cetak : 2477-5673 ISSN Online : 2614-733X Volume VI Nomor 1, Juni 2020

dengan baik dapat memberikan peluang menjadi seseorang yang berkompeten, salah satunya di dunia jurnalistik, dapat menciptakan tulisan anekdot yang unik dan tentunya dapat memberikan hiburan sekaligus kritik dan amanat yang bermanfaat sebagai kontrol sosial untuk negeri. Namun, kenyataan di lapangan menunjukkan bahwa siswa belum mampu melaksanakan kegiatan tersebut secara optimal. Masih ada beberapa faktor yang menjadi kendala dalam pembelajaran yaitu siswa menganggap bahwa kegiatan menulis teks anekdot adalah kegiatan yang sulit dan membosankan.

Berdasarkan hasil observasi ke sekolah, keterampilan menulis memang jarang diberikan di sekolah, karena guru beranggapan bahwa siswa cukup kesulitan dalam menuangkan ide-ide yang ada ke dalam bentuk tulisan. Padahal Kompetensi Dasar menulis di tingkat SMA kelas $X$ adalah mengungkapkan makna dan langkah retorika dalam bentuk esai pendek sederhana dengan menggunakan ragam tulis secara akurat, lancar dan berterima untuk berinteraksi dengan lingkungan terdekat dalam teks berbentuk anekdot yaitu dengan indikator menyusun teks anekdot dan menulis teks anekdot. Oleh karena itu, guru bahasa Indonesia dituntut untuk dapat melakukan berbagai upaya untuk meningkatkan kemampuan ide dan gagasannya ke dalam tulisan atau karangan guna mencapai tujuan pembelajaran yang ditetapkan sebelumnya.

Untuk meningkatkan kemampuan menulis siswa perlu adanya inovasi dalam pelaksanaan pembelajaran di kelas. Berbagai teknik dapat digunakan untuk mengoptimalkan pembelajaran menulis teks anekdot. Teknik yang sering digunakan dalam pembelajaran sangat umum sehingga sangat berpengaruh terhadap kemampuan berpikir siswa. Dalam penelitian ini teknik yang digunakan dalam pembelajaran di kelas adalah teknik show not tell. Teknik show not tell merupakan teknik mengubah tulisan deskripsi menjadi gambaran gambaran yang lebih hidup bagi para pembaca, sehingga orang tidak hanya membaca dan memahami, tetapi ikut terlibat dan merasakan. Teknik show not tell merupakan salah satu cara mendorong siswa untuk menulis teks anekdot dengan imajinasinya. 
Didaktik : Jurnal IImiah PGSD STKIP Subang, ISSN Cetak : 2477-5673 ISSN Online : 2614-733X Volume VI Nomor 1, Juni 2020

Teknik show not tell efektif diterapkan dalam pembelajaran menulis teks anekdot. Tiap kalimat yang dibuat dapat terbentuk secara alami dan berkesan hidup. Penulis seakan-akan dapat memberikan nyawa terhadap tulisannya, sehingga pembaca dapat memahami dan ikut merasakan apa yang dituliskan ke dalam cerita (De Porter dan Hernacki 2016:190). Manfaat teknik show not tell, yakni:

a. Mempercepat

penyusunan gagasan dalam menulis karena dibantu dengan gagasan/ide

b. Pengelompokkan kata, urutan gagasan dan melatih siswa berfikir logis, sistematis dan terstruktur.

Teknik show not tell mempunyai kelebihan yang dimiliki yaitu:

a. Teknik ini tidak membatasi penulis mencurahkan imajinasi serta kreativitasnya ke dalam tulisan.

b. Teknik Show not tell membebaskan imajinasi penulis, sehingga penulis

dapat melakukan proses kreativitasnya secara penuh.

c. Teknik show not tell memberikan kemudahan bagi siswa untuk melaksanakan

tugas berdasarkan petunjuk guru.

d. Teknik show not tell dapat melatih dan membiasakan siswa untuk bermain-main kata secara tepat.

Pengembangan teknik show not tell menurut De Porter (2007) dimulai dari mendaftar kalimat sebagai berikut:

a. Guru meminta siswa membuat daftar. Daftar yang dimaksud adalah kalimat yang memberitahukan

b. Guru menyuruh siswa mengubah kalimat menjadi paragraf

c. Beberapa siswa secara sampel membacakan hasil pekerjaannya di depan siswa dan siswa lain menanggapinya

d. Siswa mempertukarkan pekerjaannya untuk dikoreksi dan diberi nilai.

e. Siswa dan guru mereflesikan bersamasama tentang tugas siswa.

Tahap-tahap proses penulisan menggunakan teknik Show Not Tell menurut De Porter dan Hernacki (2016:194) menyatakan bahwa 
Didaktik : Jurnal IImiah PGSD STKIP Subang, ISSN Cetak : 2477-5673 ISSN Online : 2614-733X Volume VI Nomor 1, Juni 2020

proses penulisan yang efektif melalui teknik show not tell yaitu :

a. Persiapan

Pada tahap ini penulis hanya membangun fondasi untuk topik yang berdasarkan pada pengetahuan, gagasan, dan pengalaman.

b. Draft kasar

Dalam tahap ini penulis mulai menelusuri dan mengembangkan gagasan - gagasan. Kembangkan gagasan sehingga kalimat yang ditulis dapat menciptakan gambaran cerita sehingga pembaca mampu merasakan cerita yang dibuat. Pusatkan isi cerita dari tanda baca, tata bahasa, dan ejaan.

c. Berbagi

Dalam mengambil jarak dengan tulisan, penulis perlu meminta orang lain untuk membaca dan memberikan umpan balik. Mintalah seorang teman untuk membaca dan mengatakan bagian-bagian mana yang merupakan bagian terkuat dari tulisan, dan bagian mana yang tidak relevan dengan tulisan.

d. Perbaikan

Setelah mendapat umpan balik tentang bagian mana yang baik dan mana yang perlu dikerjakan lagi, ulangi dan perbaiki tulisan.

e. Penyuntingan

Pada tahap ini perbaiki semua kesalahan ejaan, tata bahasa dan tanda baca. Perhatikan penggunaan kata kerja yang tepat dan kalimat-kalimatnya lengkap.

f. Evaluasi

Periksa untuk memastikan bahwa telah menyelesaikan yang telah direncanakan dan ingin disampaikan.

\section{B. Metode Penelitian}

Metode penelitian pada dasarnya merupakan cara ilmiah untu mendapatkan data dengan tujuan dan kegunaan tertentu menurut Sugiyono (2013:2). Metode yang baik adalah metode yang dapat memberikan hasil sesuai tujuan yang telah ditetapkan. Metode yang sesuai dengan masalah yang diteliti, agar peneliti dapat dilaksanakan dengan praktis dan sistematis serta mencapai tujuan yang maksimal

Metode yang digunakan pada penelitian ini adalah metode eksperimen, metode ini termasuk metode kuantitatif. Menurut Sugiyono (2015:72). Jenis metode eksperimen yang digunakan adalah One Group 
Didaktik : Jurnal IImiah PGSD STKIP Subang, ISSN Cetak : 2477-5673 ISSN Online : 2614-733X Volume VI Nomor 1, Juni 2020

Pretest-Posttest. Tujuannya untuk memudahkan langkah-langkah dalam penelitian. Dalam penelitian ini terdapat satu kelompok yang akan diberikan tes. Pada desain ini terdapat pretest, sebelum diberikan perlakuan menggunakan teknik show not tell. Kemudian setelah diberikan perlakuan dengan teknik show not tell baru diberikan postest. Dengan demikian hasil perlakuan dapat diketahui lebih mudah. Karena dapat membandingkan dengan keadaan sebelum dan sesudah diberi perlakuan.

Desain ini digunakan secara sistematis dan terencana untuk mengetahui keefektifan teknik show no tell terhadap pembelajaran menulis teks anekdot. Desain ini dapat digambarkan sebagai berikut:

\section{$\mathrm{O}_{1} \times \mathrm{O}_{2}$}

Gambar 1.1

Pola Pretest-Posttest One-Group Design Desain penelitian eksperimen OneGroup Pretest-Posttest Design (Sugiyono, 2013:75)

Keterangan:

$\mathrm{O}_{1}=$ nilai pretest (sebelum diberi perlakuan)
$\mathrm{O}_{2}=$ nilai postest (sesudah diberi perlakuan)

Pengaruh teknik show not tell terhadap pembelajaran menulis teks anekdot $\left(\mathrm{O}_{2}-\mathrm{O}_{1}\right)$.

\section{Hasil Penelitian dan Pembahasan}

Berdasarkan data rekapitulasi nilai pretest dan posttest hasil menulis teks anekdot siswa. Nilai yang diperoleh tersebut dianalisis untuk mencari nilai Gain dan N-Gain. Nilai tersebut dilihat pada tabel 1.1 berikut ini.

\begin{tabular}{lllll}
\hline Jenis & \multicolumn{3}{c}{ Jenis Nilai } \\
Data & R & NM & NT & NR
\end{tabular}

\begin{tabular}{lcccc}
\hline Pre-test & 59,09 & 60 & 85 & 34 \\
\hline Post-test & 78,27 & 82 & 98 & 46 \\
\hline Gain & 19,18 & 17 & 47 & -3 \\
\hline N-gain & 0,45 & 0,50 & 0,95 & $-0,20$ \\
\hline \multicolumn{4}{l}{ Keterangan: } \\
R & : Nilai Rata-rata & & \\
NT & : Nilai Tertinggi & & \\
NM & : Nilai Median & & \\
NR & : Nilai Rendah
\end{tabular}

Tabel 1.1

Rekapitulasi Nilai Kemampuan Menulis Teks Anekdot

Dari tabel di atas, dapat diketahui bahwa hasil pretest dilihat dari menulis teks anekdot siswa belum cukup baik. Hal ini, terbukti dari nilai yang diperoleh siswa, yaitu nilai terendah 34 dan nilai tertinggi 85 . Berbeda dengan posttest nilai siswa dalampembelajaran menulis teks 
Didaktik : Jurnal IImiah PGSD STKIP Subang, ISSN Cetak : 2477-5673 ISSN Online : 2614-733X Volume VI Nomor 1, Juni 2020

anekdot menggunakan teknik show not tell cenderung meningkat. Dapat dibuktikan dari nilai siswa yang diperoleh dengan nilai terendah 46 dan nilai tertinggi 98. Berdasarkan kriteria indeks gain, untuk lebih jelas data distribusi diperoleh pada histogram yang terdapat pada gambar 1.2 berikut ini.

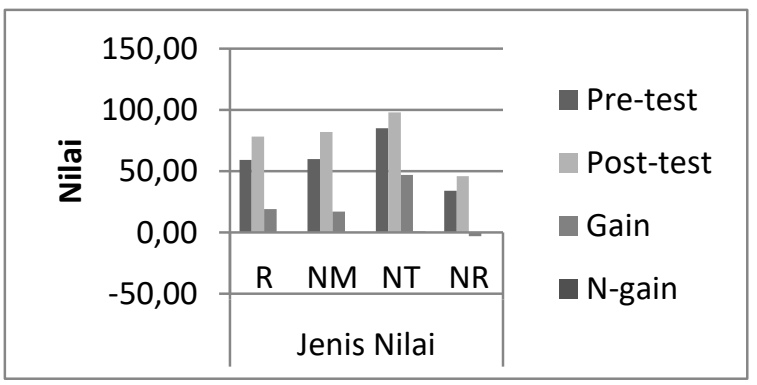

Gambar 1.2 Data Pretest, Posttest, Gaindan N-gain

Pada gambar 1.2 diketahui nilai rata-rata pretest kemampuan menulis siswa sebesar 59,09 dan mengalami peningkatan setelah menerapkan teknik show not tell pada pembelajaran menulis teks anekdot dari hasil posttest menjadi sebesar 78,27 , untuk rata-rata nilai gain yang diperoleh dari hasil penjumlahan (nilai posttest - pretest) diperoleh nilai ratarata gain sebesar 19,18.

Nilai minimal gain untuk pretest sebelum menggunakan teknik show not tell pada pembelajaran teks anekdot yaitu 34 sedangkan untuk posttest setelah menggunakan teknik show not tell meningkat menjadi 46 , dengan nilai minimal gain sebesar -3 . Nilai maksimal untuk pretest adalah 85 dan nilai maksimal untuk posttest meningkat menjadi 98 dengan nilai maksimal gain sebesar 47. Nilai median untuk pretest adalah 60 dan untuk posttest menjadi 82 dengan nilai maksimal gain sebesar 17.

Hasil yang diperoleh pada pembelajaran menulis teks anekdot sebelum menggunakan teknik show not tell dengan rata-rata nilai siswa sebesar 59,09. Dari nilai tersebut menunjukkan bahwa kemampuan siswa dalam menulis teks anekdot rendah dan belum mencapai KKM (kriteria ketuntasan minimum) yaitu $\geq$ 75. Dalam grafik yang tergambar pada perolehan ketuntasan siswa adalah 6 (18\%). Hal ini karena siswa belum mampu mengembangkan ide dan gagasan ke dalam bentuk tulisan dan belum mengetahui materi tentang teks anekdot. Setelah menggunakan teknik show not tell dan diberi perlakuan pada pembelajaran teks anekdot, hasil penilaian yang telah dianalisis dan diperoleh kemampuan menulis teks anekdot siswa meningkat cukup baik bila dibandingkan sebelum menggunakan teknik show not tell. Siswa lebih memahami pembelajaran teks 
Didaktik : Jurnal IImiah PGSD STKIP Subang, ISSN Cetak : 2477-5673 ISSN Online : 2614-733X Volume VI Nomor 1, Juni 2020

anekdot dengan materi yang ditetapkan yaitu struktur, kaidah kebahasaan, ciri-ciri, jenis-jenis anekdot.Siswa lebih aktif dan mengembangkan ide atau gagasannya dalam mempelajari teks anekdot. Adapun hasil rata-rata siswa setelah posttest yang telah diperoleh adalah 78,27 hasil menunjukkan kategori baik. Namun masih terdapat beberapa siswa yang masih kurang dari KKM yaitu $27,2 \%$, hal itu tidak mengurangi penilaian karena hasilnya semua siswa meningkat dari pretest ke posttest dapat menguasai pembelajaran teks anekdot dengan menggunakan teknik show not tell.

\section{E. Kesimpulan}

Berdasarkan hasil penelitian dan pembahasan yang telah dijelaskan pada bahasan sebelumnya maka dapat disimpulkan sebagai berikut.

1. Kemampuan menulis teks anekdot sebelum menerapkan teknik show not tell rata-ratanya sebesar 59,09. Artinya, kemampuan menulis teks anekdot masih rendah dan belum mencapai KKM (kriteria ketuntasan minimum) yaitu $\geq 75$.
2. Kemampuan menulis teks anekdot setelah menerapkan teknik show not tell sebesar 78,27. Artinya, kemampuan menulis teks anekdot mengalami peningkatan.

3. Penerapan teknik shoe not tell dalam pembelajaran menulis teks anekdot dapat dikategorikan efektif serta dapat meningkatkan kemampuan siswa dalam menulis teks anekdot.

\section{DAFTAR PUSTAKA}

Arikunto, Suharsimi. (2014). Prosedur Penelitian Suatu Pendekatan Praktik. Jakarta: Rineka Cipta.

Dalman. (2014). Keterampilan Menulis. Jakarta: Rajawali Pers.

Deporter, Bobbi dan Mike Hernacki. (2016). Quantum Learning. Bandung: Mizan Pustaka

Gino, Suwarni, Suripto, Maryanto dan Sutijan. (2000). Belajar dan Pembelajaran I. Surakarta: Departemen Pendidikan dan Kebudayaan Republik Indonesia Universitas Sebelas Maret.

Kosasih, E. M.Pd. (2016). Jenis-Jenis Teks. Bandung: Yrama Widya.

Sanjaya, Wina. (2013). Kurikulum dan Pembelajaran. Jakarta: Kencana Prenada Media Group. 
Sugiyono. (2012). Metode Penelitian Kuantitatif, Kualititatif, dan $R \& D$. Bandung: Alfabeta

Tarigan, (1985) Pengajaran Gaya Bahasa. Bandung: Angkasa

$\longrightarrow$ (1986) Materi Pokok Pendidikan Bahasa Indonesia. Jakarta:Depdikbud

,- (2008) Menulis Sebagai Suatu Berbahasa. Bandung: Angkasa 